\title{
Analisis Pengetahuan dan Ketuntasan Siswa pada Materi Bioteknologi di SMA Negeri Se-Kota Binjai
}

\author{
Sailana Mira Rangkuti ${ }^{*}$, Fauziyah Harahap ${ }^{2}$, Syahmi Edi $^{2}$ \\ ${ }^{1}$ Alumni Program Studi Pendidikan Biologi Program Pascasarjana Universitas Negeri Medan, Sumatera Utara, \\ Indonesia \\ ${ }^{2}$ Program Studi Pendidikan Biologi, Program Pascasarjana, Universitas Negeri Medan \\ *Email: sailanamhira@yahoo.co.id
}

\begin{abstract}
This research aimed to determined; (1) the level of student' knowledge on biotechnology subject matter; (2) the level student' completeness on biotechnology subject matter. This research was descriptive qualitative research. The population of this research were grade XII student from 5 senior high school in Binjai including SMA Negeri 1, SMA Negeri 2, SMA Negeri 4, SMA Negeri 6, SMA Negeri 7. Samples were chosen by using random sampling technique. Data were collecting using instrument of diagnostic test mastery on matter biotechnology and interview. The data were analyzed using descriptive percentage. Result from this research showed: (1) the average level of student' knowledge on biotechnology subject matter was 68,15 (SD $\pm 15,24)$ and categorized as good. (2) the level of student' completeness on biotechnology subject matter was (36,32\%). Based on the result of this research it can concluded the level of knowledge of students is actegorized as good but still important to improve the level of knowledge and attitude learning difficulties for more goodness result.
\end{abstract}

Keyword: The level of knowledge,Diagnostic test, Student completeness, Biotechnology, senior high school.

\section{PENDAHULUAN}

Pendidikan diharapkan dapat meningkatkan kualitas kehidupan diberbagai sektor, maka selalu dilakukan usaha perbaikan dalam proses pendidikan yang diharapkan dapat menciptakan kualitas kehidupan yang lebih baik. Penentuan perbaikan program pendidikan tersebut harus dimulai dengan melakukan penilaian terhadap pendidikan yang telah berjalan saat ini.

Dari pembelajaran yang telah berjalan dapat dilihat apakah ada kekurangan atau kelebihan dari proses pendidikan yang telah dijalankan. Perbaikan dalam proses pendidikan merupakan salah satu hal yang penting, sehingga harus dilakukan penilaian terhadap pendidikan yang sedang berjalan.

Menurut Hidayati (2013), penilaian yang mengharuskan guru untuk mengumpulkan informasi selengkaplengkapnya untuk tujuan pembuatankeputusan pengajaran, sehingga diharapkan keputusan yang diambil dapat tepat sasaran. Waktu pembelajaran terbatas yang tersedia dapat digunakan untuk pengajaran secara maksimal.
Suatu penilaian terhadap pembelajaran yang sedang berlangsung berguna dalam memperbaiki pembelajaran tersebut ke depannya. Penilaian dapat memberikan informasi mengenai kesulitan-kesulitan, tingkat pencapaian, dan kemampuan dasar siswa adalah menggunakan tes diagnostik.

Idris (2009), menyatakan bahwa dalam kesulitan belajar siswa ditunjukkan oleh adanya hambatan-hambatan tertentu untuk mencapai hasil belajar yang bersifat psikologis, sosiologis maupun fisiologis, sehingga pada akhirnya dapat menyebabkan prestasi belajar yang dicapainya berada dibawah semestinya.

Idris (2009), menyatakan bahwa dalam kesulitan belajar siswa ditunjukkan oleh adanya hambatan-hambatan tertentu untuk mencapai hasil belajar yang bersifat psikologis, sosiologis maupun fisiologis, sehingga pada akhirnya dapat menyebabkan prestasi belajar yang dicapainya berada dibawah semestinya.

Namun pada kenyataannya menurut hasil penelitian yang dilakukan Mirawati (2011) diketahui bahwa mayoritas siswa SMA yang diteliti berada pada kategori penalaran operasional konkret. Kategori 
penalaran operasional konkret adalah tahapan dimana siswa dapat menalar sesuatu yang pernah dilihatnya dalam bentuk konkret atau nyata di hadapannya. Para siswa masih memiliki keterbatasan untuk berpikir secara abstrak. Sehingga pada saat siswa mempelajari materi bioteknologi siswa mungkin akan mengalami kesulitan khususnya pada bagian bioteknologi modernnya.

Menurut Sumiar (2014), pada tahun pembelajaran 2012/2013 siswa SMP Negeri 19 Pontianak masih mengalami tingkat ketidaktuntasan KKM yang cukup tinggi sekitar $31,25 \%$ siswa yang belum tuntas pada KKM 75 pada materi bioteknologi. Hal ini disebabkan siswa mengalami kesulitan memahami pengertian bioteknologi, membedakan pergertian perbedaan bioteknologi konvensional dan modern, mengingat nama-nama mikroorganisme yang digunakan dalam produk biotek, memahami pergertian rekayasa reproduksi, memahami pengertian kultur jaringan, dan perbedaan hidroponik dan aeroponik.

Menurut hasil wawancara dengan guru biologi yang mengajar di kelas XII IPA SMA Negeri se-Kota Binjai diketahui bahwa materi bioteknologi dianggap sebagai salah satu materi yang sulit untuk diterima siswa. Materi bioteknologi dianggap sulit karena merupakan materi yang bersifat abstrak hal ini terlihat jelas pada materi bioteknologi modern. Siswa sebelumnya tidak pernah melihat secara langsung proses yang terjadi pada bioteknologi modern seperti kultur jaringan dan rekayasa genetika. Materi bioteknologi memiliki beberapa sub bab materi yang dianggap lebih sulit diterima siswa di banding sub materi lainnya.

Berdasarkan hasil wawancara dengan guru Biologi kelas XII IPA SMA Negeri seKota Binjai, beberapa sub bab materi bioteknologi yang dianggap paling sulit untuk diterima siswa diantaranya Aplikasi Bioteknologi dalam kehidupan, Rekayasa Genetika, dan Kultur Jaringan.

Selain itu dilakukan analisis terhadap nilai pada materi pembelajaran bioteknologi dari siswa tahun lalu di sekolah tersebut yakni SMA N 1 Binjai,SMA N 2 Binjai,SMA N 4 Binjai,SMA N 6 Binjai,dan SMA N 7 Binjai. Setelah diamati masih banyak siswa yang nilainya rendah dan belum mencapai KKM. Setelah memperoleh data nilai siswa dari beberapa kelas di tiap sekolah diantaranya diketahui bahwa di SMA N 1 Binjai terdapat sebanyak 52\% siswa yang belum mencapai nilai KKM yakni 83 pada materi Bioteknologi.

Pada siswa SMA N 2 Binjai dari nilai siswa di dua kelas pada tahun pelajaran yang lalu diketahui sebanyak $31 \%$ siswa belum mencapai KKM yakni 79. SMA N 4 Binjai dengan KKM 75 ada sekitar 54\% siswa yang belum lulus KKM dan di SMA N 6 Binjai dengan KKM 80 diketahui sebanyak 59,05\% sedangkan di SMA N 7 Binjai dengan KKM 75 diketahui sebanyak $38,5 \%$. Sehingga diketahui pada pelajaran di Tahun lalu untuk materi Bioteknologi masih ada sekitar 46,91\% siswa yang belum mencapai KKM pada materi Bioteknologi.

Angka tersebut cukup tinggi mengingat Bioteknologi merupakan materi yang cukup penting. Hal ini diketahui dari hadirnya soal materi Bioteknologi pada Ujian Akhir Nasional dan Seleksi masuk perguruan tinggi Negeri. Diketahui bahwa pada soal UN tahun lalu Bioteknologi materi Bioteknologi masuk pada soal no 1, 38, 39 dan 40. Pada soal seleksi masuk perguruan tinggi negeri terakhir untuk soal Saintek kode 525 diketahui Bioteknologi menjadi salah satu topik yang hadir pada soal ke 47 .

Ketika perbaikan pada proses pembelajaran dianggap sangat penting dalam menciptakan proses pembelajaran yang lebih baik lagi kedepannya maka proses tersebut dapat diawali dengan menganalisis proses pembelajaran yang telah berjalan.

Dari hasil analisis pembelajaran yang telah berjalan dapat ditemukan kelebihan dan kekurangan dari proses yang telah dilaksanakan.

MengingatmateriBioteknologimerupakansal ahsatu materi yang dianggap sulit untuk diterima siswa namun bioteknologi juga merupakan salah satu materi yang penting bagi siswa maka perlu dilakukan penelitian 
untuk mengetahui tingkat kesulitan belajar siswa.

Hal ini diharapkan mampu untuk meningkatkan pengetahuan siswa pada sub bab-sub bab tersulitnya. Sehingga pengambilan keputusan dalam pembelajaran dapat dilakukan secara tepat.

\section{METODE PENELITIAN}

Penelitian dilaksanakan di SMA Negeri se-Kota Binjai meliputi SMA Negeri 1 Binjai, SMA Negeri 2 Binjai, SMA Negeri 4 Binjai, SMA Negeri 6 Binjai dan SMA Negeri 7 Binjai. Penelitian dilakukan pada bulan Februari-Mei 2016. Populasi dalam penelitian ini adalah seluruh siswa kelas XII IPA SMA Negeri se-Kota Binjai. Pengambilan sampel dalam penelitian ini dilakukan secara acak (Random Sampling). Kota Binjai memiliki satu sekolah SMA Negeri yang mewakili setiap kecamatannya.

Jenis penelitian ini adalah penelitian deskriptif. Penelitian deskriptif ini digunakan untuk menyelidiki besar tingkat pengetahuan dan tingkat ketuntasan belajar siswa. Validasi instrumen tes diagnstic telah melalui validasi oleh dosen ahli. Selanjutnya tes diagnostik divalidasi pada siswa kelas XII SMA Negeri 3 Binjai. Setelah validasi diperoleh 25 soal pilihan berganda yang digunakan pada penelitan ini.

Fungsi diagnostik tes dengan memperhatikan alasan peserta memilih jawaban. Alasan digolongkan berdasarkan kemungkinan sumber masalah.

Tipe Kesalahan A: Jika alasan menunjukkan siswa tidak mengetahui bahasan (tidak mengisi alasan, ...karena hal tersebut adalah jawabannya).

Tipe Kesalahan B: Jika alasan menunjukkan siswa salahkonsep.

Wawancara dilakukan kepada guru Biologikelas XII IPA SMA Negeri se-Kota Binjai untuk memperoleh data awal sebagai bahan acuan bahwa penelitian perlu untuk dilakukan. Wawancara dilakukan untuk mengamati pencapaian nilai siswa pada materi Bioteknologi tahun pembelajaran 2014/ 2015. Selain itu wawancara juga dilakukan untuk mengetahui pandangan guru Biologi terhadap bagian materi tersulit untuk diterima pada materi bioteknologi.

Tingkat pengetahuan siswa merupakan nilai yang diperoleh siswa pada tes diagnostik. Sedangkan tingkat ketuntasan siswa di tunjukkan dengan persentase jumlahsiswa yang mampumencapai KKM.

\section{HASIL DAN PEMBAHASAN} Tingkat Pengetahuan Se-Kota Binjai.

SMA Negeri se-Kota Binjai memiliki sampel 278 siswa dengan perolehan nilai rata-ratahasil belajar siswa sebesar 68,15 dengan nilai tiap sekolah pada Tabel 1 berikut.

Tabel 1. Pengetahuan Se-Kota Binjai

\begin{tabular}{ccc}
\hline No & Sekolah & Nilai Rata-rata \\
\hline 1 & SMA N 1 Binjai & 60,60 \\
2 & SMA N 2 Binjai & 73,90 \\
3 & SMA N 4 Binjai & 75,58 \\
4 & SMA N 6 Binjai & 67,16 \\
5 & SMA N 7 Binjai & 63,48 \\
\hline & Se-Kota Binjai & 68,15 \\
\hline
\end{tabular}




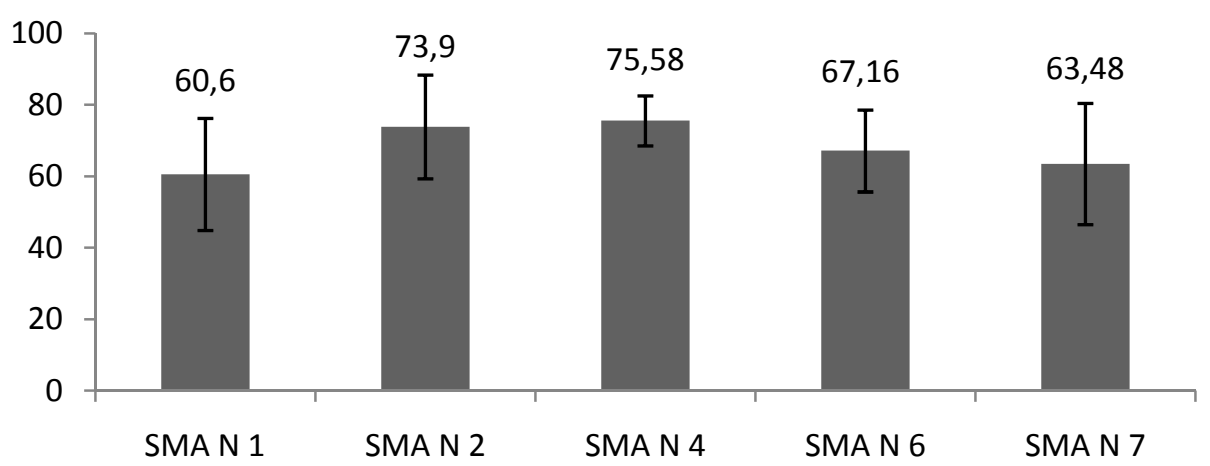

Gambar 1. Pengetahuan Se-Kota Binjai

Dari data diketahui bahwa nilai ratarata tertinggi diperoleh SMA Negeri 4 Binjai sedangkan untuk nilai rata-rata terendah diperoleh SMA Negeri 1 Binjai. Urutan perolehan dari yang tertinggi hingga yang terendah yakni SMA Negeri 4 Binjai dengan nilai rata-rata 75,58 diikuti oleh SMA Negeri 2 Binjai dengan nilai 73,9. Selanjutnya pada peringkat ketiga SMA Negeri 6 Binjai dengan perolehan nilai 67,16 dan di ikuti SMA Negeri 7 Binjai dengan nilai rata-rata 63,48 sehingga nilai terendah diperoleh SMA Negeri 1 Binjai dengan nilai rata-rata 60,6.

\section{Tingkat Pengetahuan Tiap Sekolah.}

Tingkat Pengetahuan SMANegeri 1 Binjai

Dengan jumlah sampel 86 siswa diperoleh nilai tingkat pengetahuan ratarata sebesar 60,60 . Perolehan nilai terendah 36 sebanyak 36 siswa dan nilai tertinggi 92 yang diperoleh 3 orang siswa. SMA Negeri 1 Binjai memiliki nilai terendah dibanding sekolah lainnya.

\section{Tingkat Pengetahuan SMANegeri 2 Binjai}

Siswa SMA Negeri 2 Binjai memperoleh nilai terendah 44 yang diperoleh 2 siswa dan nilai tertinggi 92 diperoleh 2 siswa. Berdasarkan nilai ratarata sekolah lain diketahui SMA Negeri 2 Binjai memiliki nilai rata-rata tertinggi kedua se-Kota Binjai dengan nilai 73,90. SMA Negeri 2 Binjai tertinggi kedua setelah SMA Negeri 4 Binjai.
Tingkat Pengetahuan SMA Negeri 4 Binjai

SMA Negeri 4 Binjai memiliki nilai rata-rata 75,58 dan merupakan nilai ratarata sekolah tertinggi se-Kota Binjai. Nilai tertinggi yang diperoleh siswa sebesar 92 yang diraih oleh 1 orang siswa, sedangkan nilai terendah yang diperoleh sebesar 60 di raih 1 orang siswa.

\section{Tingkat Pengetahuan SMA Negeri 6 Binjai}

Perolehan nilai tertinggi sebesar 88 yang diraih oleh 1 orang siswa dengan nilai terendah 44 yang juga diraih 1 orang siswa. SMA Negeri 6 Binjai memiliki nilai ratarata tertinggi ketiga Se-Kota Binjai, setelah SMA Negeri 4 dan SMA Negeri 2 Binjai dengan nilai rata-rata sebesar 67,16 .

\section{Tingkat Pengetahuan SMA Negeri 7 Binjai}

SMA Negeri 7 Binjai memiliki nilai rata-rata tertinggi keempat Se-Kota Binjai, yakni setelah SMA Negeri 4 Binjai, SMA Negeri 2 Binjai dan SMA Negeri 6 Binjai. SMA Negeri 7 Binjai memiliki nilai ratarata 63,48 , dengan perolehan nilai tertinggi sebesar 84 yang diraih oleh 1 orang siswa dan nilai terendah sebesar 20 yang diraih 1 orang siswa.

\section{Tingkat Ketuntasan Siswa Se-Kota Binjai}

Ketuntasan belajar siswa ditunjukkan dengan jumlah siswa untuk mencapai KKM sebagai Kriteria Ketuntasan Minimal.Ketuntasan siswa ditunjukkan pada Gambar 2 berikut. 


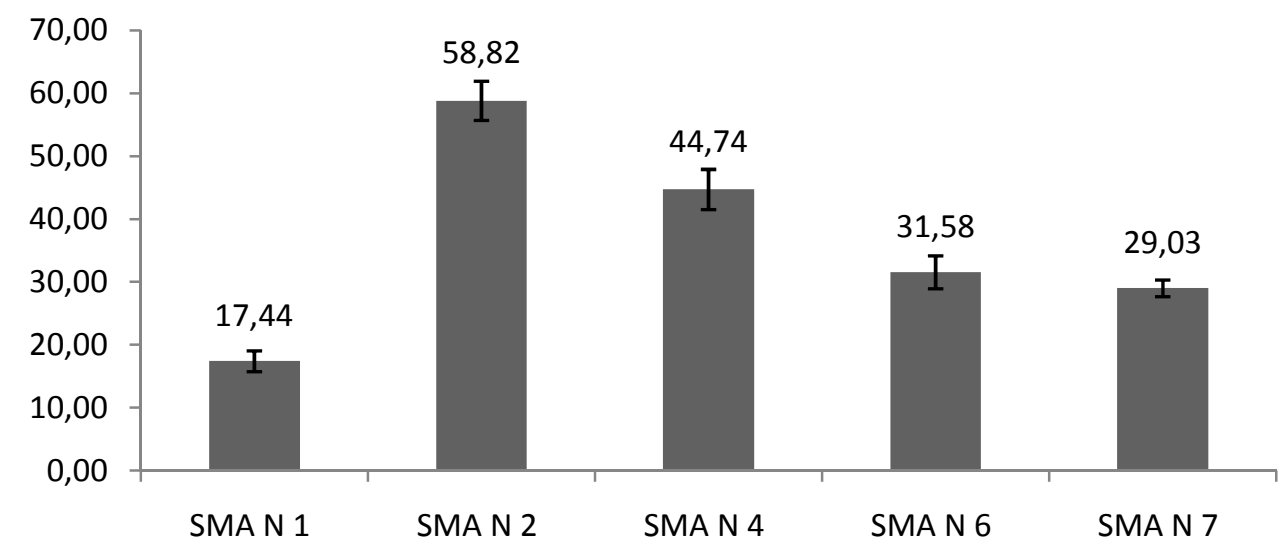

Gambar 2. Ketuntasan Se-Kota Binjai (\%)

Ketuntasan tertinggi terdapat pada SMA Negeri 2 Binjai yaitu sebesar 58,82\%. Dengan kriteria ketuntasan minimal sebesar 79 terdapat 50 siswa yang mencapai KKM dari total 85 siswa. Selanjutnya tingkat ketuntasan kedua tertinggi terjadi di SMA Negeri 4 Binjai yakni 44,74\%. Dengan kriteria ketuntasan minimal 80 diketahui 17 siswa mencapai KKM dari total 38 siswa.

Tingkat ketuntasan ketiga tertinggi terjadi di SMA Negeri 6 Binjai yakni sebesar 31,58\%. Dengan kriteria ketuntasan minimal 80 diketahui terdapat 12 siswa yang mencapai KKM dari total 38 siswa.Tingkat ketuntasan keempat tertinggi terjadi di SMA Negeri 7 Binjai yakni 29,03\%. Dengan kriteria ketuntasan minimal 78 diketahui 9 siswa mencapai KKM dari total 31 siswa. Dan tingkat ketuntasan terendah terjadi di SMA Negeri 1 Binjai. Dengan KKM 85 diketahui sebanyak 15 siswa mencapai KKM dari total 86 siswa.

\section{Tingkat Ketuntasan Tiap Sekolah}

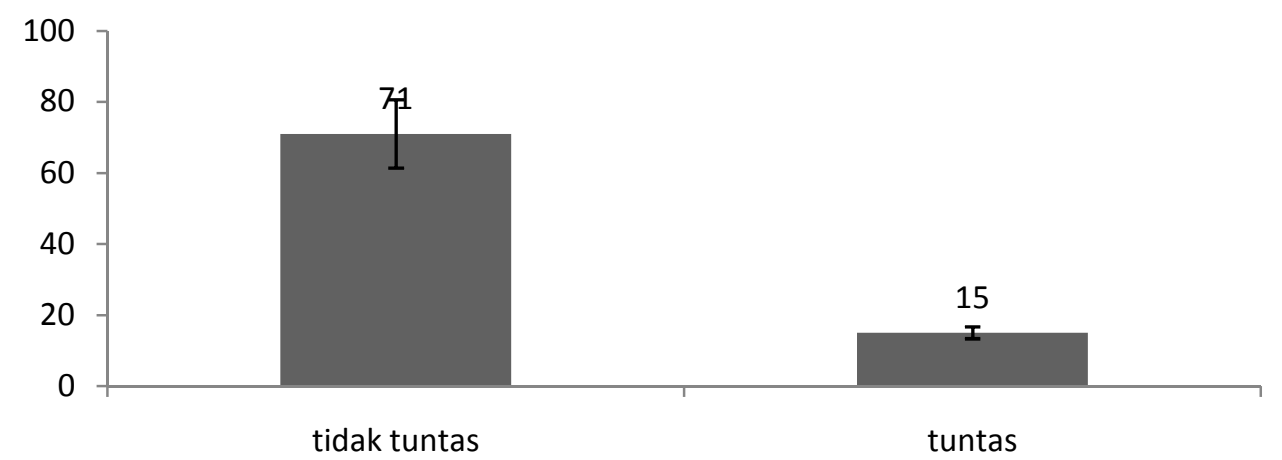

Gambar 3. Ketuntasan SMA N 1 Binjai memiliki 15 siswa yang mampu mencapai KKM atau sekitar $17,44 \%$

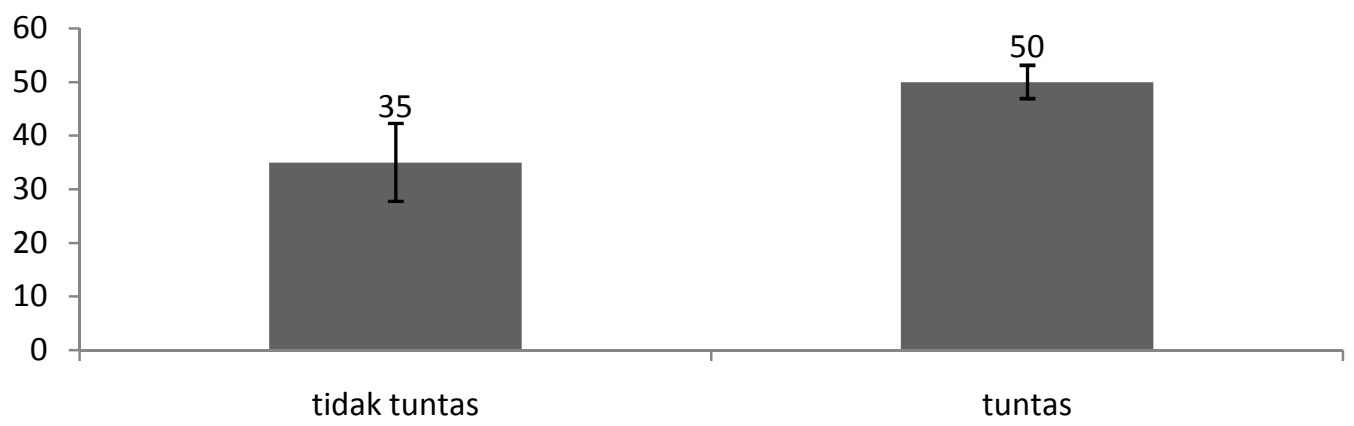

Gambar 4. Ketuntasan SMA N 2 Binjai terdapat 50 siswa yang mampu mencapai KKM sekitar $58,82 \%$ 


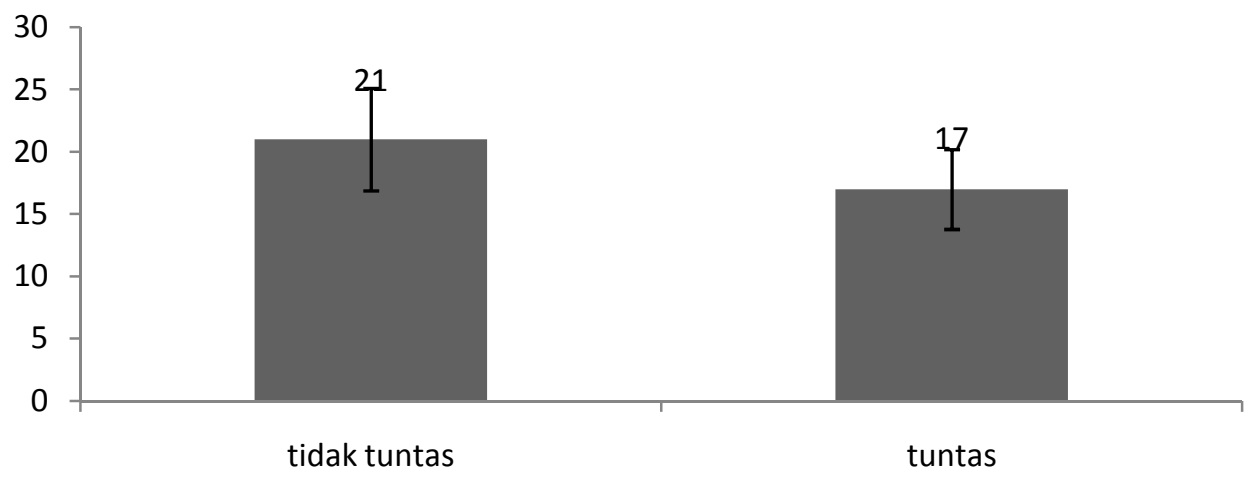

Gambar 5. Ketuntasan SMA N 4 Binjai terdapat 12 siswa yang mampu mencapai KKM sekitar $31,58 \%$

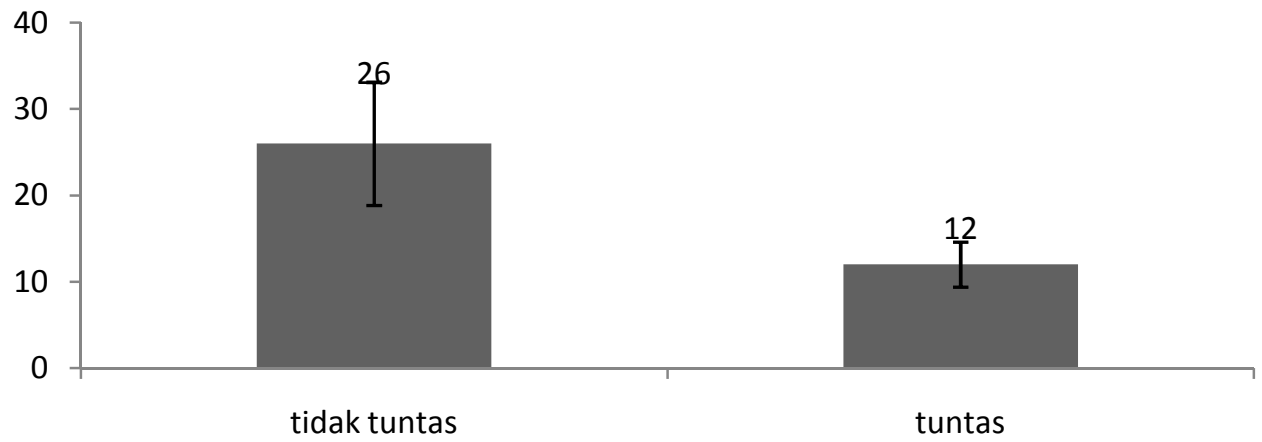

Gambar 6. Ketuntasan SMA N 6 Binjai terdapat 12 siswa yang mampu mencapai KKM sekitar $31,58 \%$

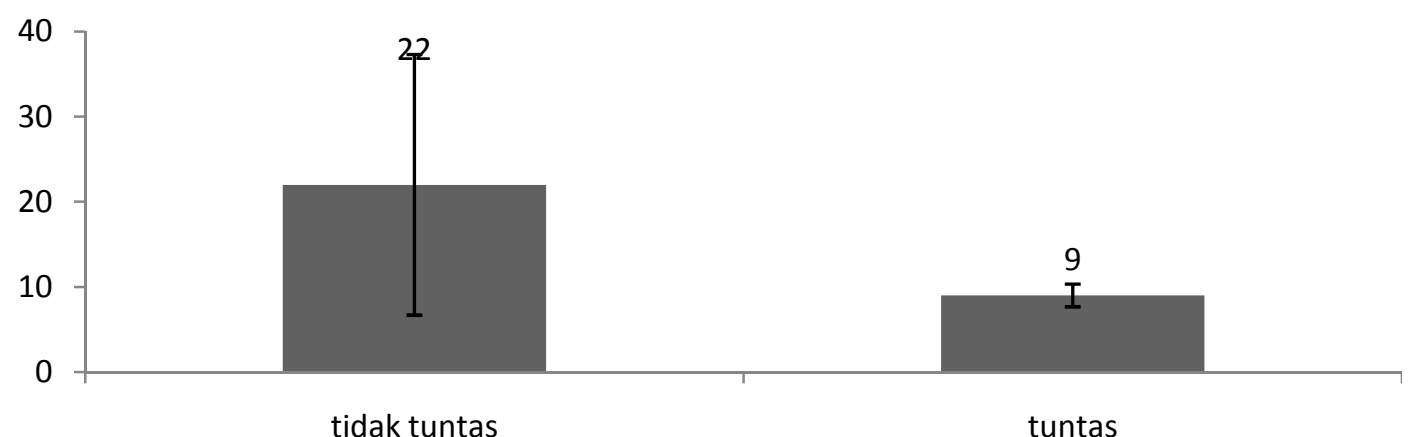

Gambar 7. Ketuntasan SMA N 7 Binjai terdapat 9 siswa yang mampu mencapai KKM sekitar 29,03\%

\section{SIMPULAN}

Tingkat pengetahuan siswa SMA Negeri seKota Binjai sebesar 68,15 yang tergolong dalam kategori baik. Tingkat pengetahuan siswa per-sekolah dari perolehan nilai tertinggi ke terendah sebagai berikut SMA N 4 Binjai termasuk kategori baik $(75,58)$, SMA N 2 Binjai termasuk kategori baik $(73,90)$, SMA Negeri 6 Binjai termasuk kategori baik $(67,16)$, SMA Negeri 7 Binjai termasuk kategori baik $(63,48)$ dan SMA Negeri 1 Binjai termasuk kategori cukup $(60,60)$. Tingkat ketuntasanbelajarsiswa SMA Negeri se-Kota Binjai dengan perolehan nilai sebesar $36,32 \%$ termasuk kategori kurang baik. Tingkat ketuntasanbelajarsiswa SMA Negeri seKota Binjai di tiap Sekolah adalah sebagai berikut SMA Negeri 1 Binjai sebesar $17,44 \%$ termasuk kategori buruk, SMA Negeri 2 Binjai sebesar 58,82\% termasuk kategori cukup, SMA Negeri 4 Binjai sebesar $44,74 \%$ termasuk kategori cukup dan SMA Negeri 6 Binjai sebesar 31,58\% termasuk kategori kurang baik dan SMA Negeri 7 sebesar 29,03\% termasuk kategori kurang baik.

\section{DAFTAR PUSTAKA}

Hidayati, T., Nugroho, S.E., \& Sudarmin. 2013. Pengembangan Tes Diagnostik Untuk Mengidentifikasi Keterampilan Proses Sains 
Dengan Tema Energi Dalam Pembelajaran IPA Terpadu. Semarang : Universitas Negeri Semarang.

Idris, R. 2009. Mengatasi Kesulitan Belajar dengan Pendekatan Psikologi Kognitif. Jurnal Lentera Pendidikan (12) no. 2

Mirawati, R. 2011. Profil Kemampuan Penalaran Ilmiah dan Penguasaan Konsep Siswa SMA Kelas XI pada Konsep Sistem
Pencernaan Melalui Model Pembelajaran Kooperatif Tipe STAD. Skripsi Jurusan Pendidikan Biologi UPI: tidak diterbitkan.

Sumiar.,Putri,R.G., dan Wahyuni,E.S. 2014. Upaya Meningkatkan Hasil Belajar siswa melalui pembelajaran Direct Instruction Pada Materi Bioteknologi Kelas IX SMP B. Pontianak: FKIP UNTAN. 